\title{
11/-hydroxysteroid dehydrogenases as targets in the treatment of steroid-associated femoral head necrosis using antler extract
}

\author{
RIBUSURONG PU ${ }^{1}$ and $\mathrm{HAO} \mathrm{PENG}^{2}$ \\ ${ }^{1}$ Orthopaedics Department, The Affiliated Hospital of Inner Mongolia Medical University, Hohhot, Inner Mongolia 010050; \\ ${ }^{2}$ Orthopaedics Department, Renmin Hospital of Wuhan University, Wuhan, Hubei 430060, P.R. China
}

Received September 21, 2016; Accepted August 1, 2017

DOI: $10.3892 /$ etm.2017.5459

\begin{abstract}
The aim of the present study was to investigate the therapeutic effect of deer antler extract on avascular necrosis of the femoral head (ANFH) induced by steroids, and to confirm that $11 \beta$-hydroxysteroid dehydrogenases (11 $\beta$-HSD) are one of the targets of treatment with antler extract. A total of 30 rabbits were randomly divided into 5 groups $(n=6)$ : A control, ANFH, ANFH + antler $(250 \mathrm{mg} / \mathrm{kg}), \mathrm{ANFH}+$ antler $(500 \mathrm{mg} / \mathrm{kg})$ and ANFH + antler $(1,000 \mathrm{mg} / \mathrm{kg})$ group. Rabbits in the experimental groups were injected with methylprednisolone and horse serum to establish a steroid-induced ANFH (SANFH) model. Rabbits in the ANFH + antler $(250 \mathrm{mg} / \mathrm{kg})$, $\mathrm{ANFH}+\operatorname{antler}(500 \mathrm{mg} / \mathrm{kg})$ and ANFH + antler $(1,000 \mathrm{mg} / \mathrm{kg})$ groups were treated with intraperitoneal injection of 250,500 or $1,000 \mathrm{mg} / \mathrm{kg}$ antler extract/day, respectively, for 60 days. Serum samples were then extracted to determine total cholesterol (CT) and triglyceride levels, treat osteoblasts, measure $11 \beta$-HSD (11 $\beta$-HSD1) and 11 $\beta$-HSD2 and alkaline phosphatase (ALP) levels and cellular apoptosis, and determine the proportion of osteoblasts in each phase of the cell cycle. Serum $\mathrm{CT}$ and triglyceride levels in SANFH rabbits significantly decreased as the concentration of antler increased $(\mathrm{P}<0.05)$. $11 \beta$-HSD1 levels in the femoral heads of SANFH rabbits and osteoblasts following treatment with antler-containing serum decreased as the concentration of antler used increased, whereas levels of $11 \beta$-HSD1 increased significantly $(\mathrm{P}<0.05)$. The proliferation of osteoblasts and ALP levels in osteoblasts increased as the antler concentration increased, whereas the number of osteoblasts in the G0/G1 phase decreased significantly $(\mathrm{P}<0.05)$. The current study demonstrated that treatment with antler extract has a therapeutic effect on ANFH induced by steroids in rabbits and may regulate the expression
\end{abstract}

Correspondence to: Professor Hao Peng, Orthopaedics Department, Renmin Hospital of Wuhan University, 99 Zhangzhidong Road, Wuchang, Wuhan, Hubei 430060, P.R. China

E-mail: penghaowuda@163.com

Key words: antler, femoral head necrosis, steroid, 11ß-hydroxysteroid dehydrogenases of $11 \beta$-HSD in femoral heads and osteoblasts, as well as promoting the proliferation of osteoblasts.

\section{Introduction}

Osteonecrosis of the femoral head (ONFH) is caused by the interruption of the blood supply to the femoral head or the pathological process of osteoblast death $(1,2)$. Steroid-induced avascular necrosis of the femoral head (SANFH) is a type of non-traumatic ANFH and the most common type of femoral head necrosis. It occurs following the long-term use of adrenocorticotropic hormones (ACTH) or the use of high doses of ACTHs (3-5). The major clinical characteristics of ANFH include hip pain, limited mobility, lameness and a high disability rate, which negatively impact patient health and quality of life (6-8). It is estimated that $\sim 50 \%$ of all ONFH cases are induced by ACTH $(5,9,10)$. In China, there are 5-7.5 million patients with ONFH requiring treatment and the number of new ONFH cases was 150,000-200,000 in 1998, with the majority of cases diagnosed in young adults (11).

Corticosteroids are widely used to treat several diseases, including asthma (12), nephritic syndrome (13) and leukemia (14), as they suppress inflammation, allergic reactions and the immune response. However, in the process of producing marked improvements in the symptoms of these diseases, corticosteroids induce certain adverse effects, including growth retardation (15), obesity (16), osteoporosis (17), hyperglycemia (18), osteonecrosis (19), cataracts (20) and Cushing's syndrome (21), which limits their use clinically. Therefore, increasing attention has been given to identifying methods of treating corticosteroid-induced ANFH (22-25).

Currently, patients with advanced ANFH receive hip arthroplasty, whereas those at the pre-collapse stage receive salvage surgery; however, for patients with non-traumatic ANFH, as well as those for whom surgery would be high-risk, non-surgical treatment is more appropriate (26). Numerous studies have been conducted to investigate the potential of novel drugs, including statins (27) and alendronate (28) to treat ANFH without surgery; however, to date, their therapeutic effects have been unsatisfactory. For many years, Traditional Chinese Medicine (TCM) has been widely used to treat different diseases involving the bone, and deer antlers are often used in TCM $(29,30)$. The outside of the antlers consist of skin covered with hair, while the inner antler is made up 
of connective tissue, cartilaginous tissue, blood vessels and abundant nerves (31). It has been reported that antlers may have preventive and therapeutic effects on osteoporosis (32) and may also help with sperm production and strengthen the muscles and bones (33). However, there have been few papers investigating the therapeutic effect of deer antler extracts on femoral head necrosis.

The 11 $\beta$-hydroxysteroid dehydrogenase (11 $\beta$-HSD) family of enzymes, which includes $11 \beta-H S D 1$ and 11 $\beta$-HSD2, catalyze the interconversion of active glucocorticoids (34). Previous studies have demonstrated that $11 \beta$-HSD1 and $11 \beta$-HSD2 influence the function of adipocytes and endotheliocytes $(35,36)$. Adipocyte and endotheliocyte dysfunction may cause blood flow in the terminal vessels to become abnormal and induce complications, including intravascular coagulation, microcirculation disturbance and vascular embolization, which in turn may lead to femoral head necrosis (37). The phenomenon indicates that $11 \beta$-HSD may be important in the development of SANFH.

The current study used antler extract to treats rabbit with SANFH and measured the expression of $11 \beta$-HSD to confirm that $11 \beta$-HSD was one of the targets in the treatment of SANFH using antler extract.

\section{Materials and methods}

Antler preparation. Mature deer antlers were obtained from Beijing Tong Ren Tang Chinese Medicine Co., Ltd., (Beijing, China). A total of $200 \mathrm{~g}$ antler was dried, milled and sliced, and then extracted 4 times by dissolving in 11 distilled water and boiling for $5 \mathrm{~h}$. Following filtration with 3 levels of sterile gauze (TZSB; Beijing Solarbio Science \& Technology Co.,Ltd., Beijing, China), the liquid containing the antler extract was concentrated at $20 \%$ by boiling for $5 \mathrm{~h}$ and stored at $4^{\circ} \mathrm{C}$ for 3 days.

Animals. A total of 30 male New Zealand rabbits, 4 months old and weighing 2.6-3.2 kg, were obtained from the Experimental Animal Center of the Affiliated Hospital of Inner Mongolia Medical University (Hohot, China). Rabbits were housed in an animal chamber maintained at $22 \pm 2^{\circ} \mathrm{C}$ with a relative humidity of $50 \pm 5 \%$ and a $12 / 12 \mathrm{~h} \mathrm{light/dark} \mathrm{cycle.} \mathrm{Access}$ to food and water was ad libitum. All animal experiments in the present study were approved by the Animal Care and Use Committee of the Affiliated Hospital of Inner Mongolia Medical University (Hohhot, China) and followed the ethical guidelines set by the European Community guidelines (38).

Establishment of SAMFH rabbit model. SANFH rabbit models were established following a previously described method $(39,40)$. The 30 healthy New Zealand rabbits were randomly divided into 5 groups $(n=6)$ : A control, ANFH, ANFH + antler $(250 \mathrm{mg} / \mathrm{kg})$, ANFH + antler $(500 \mathrm{mg} / \mathrm{kg})$ and $\mathrm{ANFH}+$ antler $(1,000 \mathrm{mg} / \mathrm{kg})$ group. All rabbits received an injection of $10 \mathrm{ml} / \mathrm{kg}$ horse serum (100\%; Thermo Fisher Scientific, Inc., Waltham, MA, USA) via the ear vein for 2 weeks. Subsequently, $6 \mathrm{ml} / \mathrm{kg} /$ day horse serum was injected for 2 days.

Rabbits in the experimental groups received an intraperitoneal injection of $20 \mathrm{mg} / \mathrm{kg}$ methylprednisolone (Sigma-Aldrich; Merck KGaA, Darmstadt, Germany) twice a week, over a 2-week period. Rabbits in the control group were intraperitoneally injected with the same volume of saline. Subsequently, 200,000 U penicillin was injected into the buttock of each rabbit. After 2 weeks, 1 rabbit in each group was randomly selected to confirm whether the SANFH model was successfully established by performing a femoral head histopathological examination. The femoral head was separated and fixed with $2 \%$ glutaraldehyde at $4{ }^{\circ} \mathrm{C}$ overnight (Beijing Solarbio Science \& Technology Co., Ltd.), decalcified with 5\% nitric acid (Beijing Solarbio Science \& Technology Co., Ltd.), dehydrated with a graded series of ethanol $(70,80$, 90, 95 and $100 \%$ ) embedded in paraffin and cut into $5 \mu \mathrm{m}$ slices using a microtome (HM 355S; Thermo Fisher Scientific, Inc.). Sections were subsequently dewaxed with xylene, rehydrated with a graded series of ethanol $(100,95,90,80$ and $70 \%$ ) and stained with hematoxylin at $25^{\circ} \mathrm{C}$ for $10 \mathrm{~min}$ and eosin at $25^{\circ} \mathrm{C}$ for $1 \mathrm{~min}$. Stained sections were observed under a light microscope (magnification, x200).

Following confirmation of successful establishment of the SANFH model, the antler extract was dissolved in distilled water to form final concentrations of $250 \mathrm{mg} / \mathrm{kg}, 500 \mathrm{mg} / \mathrm{kg}$ and $1,000 \mathrm{mg} / \mathrm{kg}$. The different concentrations of antler extracts were administered to rabbits in the $\mathrm{ANFH}+$ antler $(250 \mathrm{mg} / \mathrm{kg}), \mathrm{ANFH}+$ antler $(500 \mathrm{mg} / \mathrm{kg})$ and ANFH + antler $(1,000 \mathrm{mg} / \mathrm{kg})$ groups, respectively, every day for 60 days by intraperitoneal injection. Rabbits in the control and ANFH groups were intraperitoneally injected with the same volume of saline.

CT and triglyceride determination. Following treatments, all rabbits were anesthetized with a combination of xylazine $(6 \mathrm{mg} / \mathrm{kg})$ and ketamine $(40 \mathrm{mg} / \mathrm{kg}$; both Seebio Biotech Co., Ltd., Shanghai, China) according to previous report and sacrificed by cervical dislocation (41). Blood was collected from the ear vein in EDTA tubes and centrifuged at $4^{\circ} \mathrm{C}$ and $5,000 \times \mathrm{g}$ to separate serum. CT and triglyceride concentrations in the blood samples of all rabbits were measured using an automatic biochemistry analyzer (Siemens AG, Munich, Germany).

Histopathological examination. Femoral heads, including the metaphyses and thighbones, of all the rabbits were collected and cut into sections. Sections were fixed in $2 \%$ glutaraldehyde (Beijing Solarbio Science \& Technology Co., Ltd., Beijing, China) at $25^{\circ} \mathrm{C}$ for $24 \mathrm{~h}$. Sections were then embedded in paraffin and cut into slices $5 \mu \mathrm{m}$ thick. Following deparaffinization and rehydration with graded ethanol, sections were stained with hematoxylin and eosin (Thermo Fisher Scientific, Inc.). Histopathological changes of the femoral heads were observed under a light microscope (Olympus Corporation, Tokyo, Japan).

Osteoblast culture. A total of 2 male newborn New Zealand rabbits, 10 days old, weight $20.17 \pm 1.03 \mathrm{~kg}$, were obtained from the Experimental Animal Center of the Affiliated Hospital of Inner Mongolia Medical University and sacrificed as described above. Rabbits were housed in an animal chamber maintained at $22 \pm 2^{\circ} \mathrm{C}$ with a relative humidity of $50 \pm 5 \%$ and a $12 \mathrm{~h}$ light/dark cycle with access to food and water ad libitum. Primary osteoblasts were obtained from newborn rabbit calvarias. Tissues 
Table I. Total cholesterol and triglycerides in the serum of rabbits with or without SANFH.

\begin{tabular}{llc}
\hline & $\begin{array}{c}\text { Total } \\
\text { cholesterol } \\
(\mathrm{mmol} / \mathrm{l})\end{array}$ & $\begin{array}{c}\text { Triglycerides } \\
(\mathrm{mmol} / \mathrm{l})\end{array}$ \\
\hline Control & $1.22 \pm 0.78$ & $0.85 \pm 0.32$ \\
SANFH & $2.58 \pm 0.90^{\mathrm{a}}$ & $1.27 \pm 0.60^{\mathrm{a}}$ \\
SANFH + antler $(250 \mathrm{mg} / \mathrm{kg})$ & $2.16 \pm 0.63^{\mathrm{a}, \mathrm{b}}$ & $1.09 \pm 0.44^{\mathrm{a}, \mathrm{b}}$ \\
SANFH + antler $(500 \mathrm{mg} / \mathrm{kg})$ & $1.72 \pm 0.59^{\mathrm{a}-\mathrm{c}}$ & $0.97 \pm 0.58^{\mathrm{b}, \mathrm{c}}$ \\
SANFH + antler $(1,000 \mathrm{mg} / \mathrm{kg})$ & $1.57 \pm 0.81^{\mathrm{b}, \mathrm{c}}$ & $0.92 \pm 0.49^{\mathrm{b}, \mathrm{c}}$ \\
\hline
\end{tabular}

Data are presented as the mean \pm standard deviation. $\mathrm{n}=25$. ${ }^{\mathrm{a}} \mathrm{P}<0.05$ vs. control group; ${ }^{\mathrm{b}} \mathrm{P}<0.05$ vs. $\mathrm{SANFH}$ group, $\mathrm{P}<0.05$; ${ }^{\mathrm{c}} \mathrm{P}<0.05 \mathrm{vs}$. SANFH + antler $(250 \mathrm{mg} / \mathrm{kg})$ group. SANFH, steroid-associated femoral head necrosis.

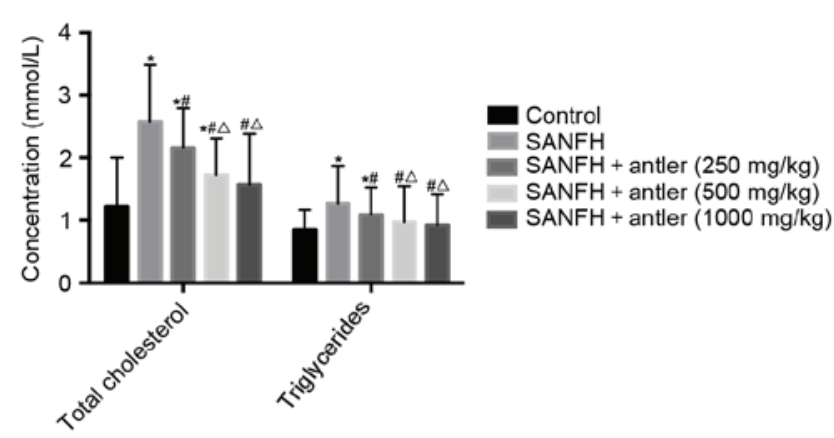

Figure 1. Total cholesterol and triglycerides in the serum of rabbits with or without SANFH following treatment with different concentrations of antler extract. " $\mathrm{P}<0.05$ vs. control group; ${ }^{\#} \mathrm{P}<0.05$ vs. SANFH group; ${ }^{\Delta} \mathrm{P}<0.05$ vs. SANFH + antler $(250 \mathrm{mg} / \mathrm{kg})$ group. SANFH, steroid-induced avascular necrosis of the femoral head.

were digested with trypsin 3 times and incubated with type I collagenase and $0.25 \%$ trypsin-EDTA in Hank's buffer solution (all Thermo Fisher Scientific, Inc.). The tissues were then cut into pieces $<0.5 \mathrm{~mm}^{3}$ and placed on the inner surface of the dish to release the cells. Cells were cultured with Dulbecco's Modified Eagle medium (DMEM; Thermo Fisher Scientific, Inc.) containing $10 \%$ fetal bovine serum (Thermo Fisher Scientific, Inc.), $100 \mathrm{U} / \mathrm{ml}$ penicillin and $100 \mathrm{U} / \mathrm{ml}$ streptomycin (Sigma-Aldrich; Merck KGaA) at $37^{\circ} \mathrm{C}$ in $5 \% \mathrm{CO}_{2}$ for $24 \mathrm{~h}$. The tissues were then washed with $1 \mathrm{X}$ PBS to discard unattached cells. The medium was replenished every 2-3 days and cells were passaged until $90 \%$ confluence was reached.

Antler serum treatment. Osteoblasts were seeded at $1 \times 10^{6} / \mathrm{ml}$ and cultured in a 96 -well plate. Cells from rabbits in the 5 groups including the control, ANFH, ANFH + antler $(250 \mathrm{mg} / \mathrm{kg})$, $\mathrm{ANFH}+\operatorname{antler}(500 \mathrm{mg} / \mathrm{kg})$ and $\mathrm{ANFH}+\operatorname{antler}(1,000 \mathrm{mg} / \mathrm{kg})$ groups and there were 3 replicates from each group. A total of $40 \mu \mathrm{l}$ methylprednisolone solution $(1 \mu \mathrm{mol} / \mathrm{l})$ was added to the ANFH, ANFH + antler $(250 \mathrm{mg} / \mathrm{kg}), \mathrm{ANFH}+$ antler $(500 \mathrm{mg} / \mathrm{kg})$ and ANFH + antler $(1,000 \mathrm{mg} / \mathrm{kg})$ groups, while $40 \mu \mathrm{g} / \mathrm{DMEM}$ was added to the cells in the control group. Following incubation for $24 \mathrm{~h}$, medium was replenished and serum samples collected from the rabbits $(1: 40)$ were added to the corresponding group of cells for $24 \mathrm{~h}$.

Western blotting. Total proteins from the femoral head tissue or the cells treated with antler serum were extracted using radioimmunoprecipitation assay buffer (Thermo Fisher Scientific, Inc.) and measured using the BCA method (Thermo Fisher Scientific, Inc.). A total of $75 \mu \mathrm{g}$ protein was analyzed using sodium dodecyl sulfate-polyacrylamide gel electrophoresis (SDS-PAGE) with a 10\% separating gel and 5\% stocking gel. Following SDS-PAGE, proteins were transferred to a polyvinylidene difluoride membrane (Merck KGaA). The membrane was blocked with $5 \%$ skimmed milk at $25^{\circ} \mathrm{C}$ for $2 \mathrm{~h}$. Rabbit anti-11 $\beta$-HSD1 and rabbit anti-11 $\beta$-HSD2 primary antibodies (1:1,000, Wuhan Sanyang Biotechnology, Wuhan, China) were incubated with the membrane at $4^{\circ} \mathrm{C}$ overnight. Membranes were washed with PBS 3 times for 7 min. Membranes were incubated with goat anti-rabbit secondary antibodies (Jackson ImmunoResearch Laboratories, Inc., West Grove PA, USA) at $25^{\circ} \mathrm{C}$ for $1 \mathrm{~h}$. $\beta$-actin was used as an internal control. An electrochemiluminescence system (Thermo Fisher Scientific, Inc.) was used for exposure.

Alkaline phosphatase (ALP) detection. Following treatment with antler serum for $72 \mathrm{~h}, 20 \mu 10.05 \%$ Triton X-100 was added to each well and incubated at $25^{\circ} \mathrm{C}$ for $5 \mathrm{~min}$ to induce cell lysis. An ALP assay kit (AP0100-1KT; Sigma-Aldrich; Merck KGaA) was used to detect ALP levels in the blood serum and osteoblasts. A total of $980 \mu \mathrm{l}$ (blank) and $960 \mu \mathrm{l}$ (test and control) of reaction buffer was pipetted into cuvettes and $20 \mu \mathrm{l}$ of $0.67 \mathrm{M}$ pNPP solution was added to each cuvette and equilibrated at $37^{\circ} \mathrm{C}$. Subsequently, $20 \mu 1$ of sample was added to each test cuvette, and $20 \mu \mathrm{l}$ of diluted ALP solution was added to the enzyme control cuvette. Cuvettes were mixed by inversion and the $\mathrm{A}_{405} \mathrm{~nm}$ was recorded (SpectraMax i3X plant reader; Molecular Devices, LLC, Sunnyvale, CA, USA). Obtained the maximum linear rate $\left(\Delta \mathrm{A}_{405} \mathrm{~nm} /\right.$ minute).

Measurement of cell proliferation. Following treatment with antler serum for $72 \mathrm{~h}, 10 \mu \mathrm{l}$ cell counting kit-8 (Thermo Fisher Scientific, Inc.) was added to each well and incubated at $37^{\circ} \mathrm{C}$ for $20 \mathrm{~min}$. An automatic biochemistry analyzer was used to measure the optical density (OD) value at $450 \mathrm{~nm}$.

Cell cycle analysis. Following treatment with antler serum for $72 \mathrm{~h}$, cells were collected and fixed in pre-cooled $70 \%$ ethanol at $4^{\circ} \mathrm{C}$ overnight. A Cell Cycle and Apoptosis Analysis kit (C1052, Beyotime Institute of Biotechnology) was used to assess the cell cycle according to the manufacturer's protocol. A flow cytometer (Cytomics FC 500; Beckman Coulter, Inc., Brea, CA, USA) was used to detect and determine the proportion of cells in each phase of the cell cycle.

Statistical analysis. All data were analyzed using SPSS 19.0 software (IBM Corp, Armonk, NY, USA) and presented as the mean \pm standard deviations. One-way ANOVA followed by Dunnett's test was used for comparison and analysis between groups. $\mathrm{P}<0.05$ was considered to indicate a statistically significant difference. 


\section{Results}

CT and triglyceride concentration. CT and triglyceride levels in the blood serum of the rabbits with or without SAFHN are presented in Table I and Fig. 1. The serum CT levels of the rabbits in the SANFH, SANFH + antler $(250 \mathrm{mg} / \mathrm{kg})$ and SANFH + antler $(500 \mathrm{mg} / \mathrm{kg})$ groups $(2.58 \pm 0.90 \mathrm{mmol} / 1$, $2.16 \pm 0.63 \mathrm{mmol} / 1$ and $1.72 \pm 0.59 \mathrm{mmol} / \mathrm{l})$ were significantly higher $(\mathrm{P}<0.05)$ than that of the control $(1.22 \pm 0.78 \mathrm{mmol} /)$. Serum CT levels in the SANFH + antler $(1,000 \mathrm{mg} / \mathrm{kg})$ group $(1.57 \pm 0.81) \mathrm{mmol} / \mathrm{l}$ were higher than that of the control, but not significantly. Furthermore, serum CT levels in the SANFH + antler $(250 \mathrm{mg} / \mathrm{kg}), \mathrm{SANFH}+\operatorname{antler}(500 \mathrm{mg} / \mathrm{kg})$ and $\mathrm{SANFH}+$ antler $(1,000 \mathrm{mg} / \mathrm{kg})$ groups were all significantly lower than that of the SANFH group (all $\mathrm{P}<0.05$ ) and serum CT levels in the SANFH + antler $(500 \mathrm{mg} / \mathrm{kg})$ and $\mathrm{SANFH}+$ antler $(1,000 \mathrm{mg} / \mathrm{kg})$ groups were significantly lower than that of the SANFH + antler $(250 \mathrm{mg} / \mathrm{kg})$ group $(\mathrm{P}<0.05)$. Serum CT levels did not differ significantly between the SANFH + antler $(1,000 \mathrm{mg} / \mathrm{kg})$ and SANFH + antler (500 mg/kg) groups (Fig. 1 and Table I).

Serum triglyceride levels of the rabbits in the SANFH and SANFH + antler $(250 \mathrm{mg} / \mathrm{kg})$ groups $(1.27 \pm 0.60 \mathrm{mmol} / \mathrm{l}$ and $1.09 \pm 0.44 \mathrm{mmol} / 1$, respectively) were significantly higher $(\mathrm{P}<0.05)$ than that of the control $(0.85 \pm 0.32 \mathrm{mmol} / \mathrm{l})$. However, serum triglyceride levels in the SANFH + antler $(500 \mathrm{mg} / \mathrm{kg})$ and SANFH + antler $(1,000 \mathrm{mg} / \mathrm{kg})$ groups $(0.97 \pm 0.58 \mathrm{mmol} / 1$ and $0.92 \pm 0.49 \mathrm{mmol} / 1$, respectively) did not differ significantly from those in the control. Serum triglyceride levels in the SANFH + antler $(250 \mathrm{mg} / \mathrm{kg}), \mathrm{SANFH}+\operatorname{antler}(500 \mathrm{mg} / \mathrm{kg})$ and SANFH + antler $(1,000 \mathrm{mg} / \mathrm{kg})$ groups were all significantly lower than those in the SANFH group $(\mathrm{P}<0.05)$. Furthermore, serum triglyceride levels in the SANFH + antler $(500 \mathrm{mg} / \mathrm{kg})$ and SANFH + antler $(1,000 \mathrm{mg} / \mathrm{kg})$ groups were significantly lower than those in the SANFH + antler $(250 \mathrm{mg} / \mathrm{kg})$ group $(\mathrm{P}<0.05)$. Levels of serum triglycerides did not differ significantly between the SANFH + antler $(1,000 \mathrm{mg} / \mathrm{kg})$ and $\mathrm{SANFH}+$ antler $(500 \mathrm{mg} / \mathrm{kg})$ group.

$11 \beta-H S D$ expression. The expression of $11 \beta-H S D 1$ and $11 \beta$-HSD2 in the rabbit tissues (Fig. 2) and osteoblasts (Fig. 3) are also presented in Table II.

In the rabbit tissues, relative $11 \beta$-HSD $(\mathrm{P}<0.05)$, SANFH + antler $(250 \mathrm{mg} / \mathrm{kg})$ and SANFH + antler $(500 \mathrm{mg} / \mathrm{kg})$ groups $(0.49 \pm 0.05,0.40 \pm 0.07$ and $0.33 \pm 0.04$, respectively) were all significantly higher than that of the control $(0.28 \pm 0.08 ; \mathrm{P}<0.05)$. However, $11 \beta$-HSD1 expression in the SANFH + antler $(1,000 \mathrm{mg} / \mathrm{kg})$ group $(0.31 \pm 0.07)$ did not differ significantly from that of the control. Furthermore, the expression of $11 \beta-H S D 1$ in the SANFH + antler $(250 \mathrm{mg} / \mathrm{kg})$, SANFH+antler $(500 \mathrm{mg} / \mathrm{kg})$ and SANFH+antler $(1,000 \mathrm{mg} / \mathrm{kg})$ groups were all significantly lower than that of the SANFH group $(\mathrm{P}<0.05)$. Levels of $11 \beta-H S D 1$ in the SANFH + antler $(500 \mathrm{mg} / \mathrm{kg})$ and SANFH + antler $(1,000 \mathrm{mg} / \mathrm{kg})$ groups were also significantly lower than in the SANFH + antler $(250 \mathrm{mg} / \mathrm{kg})$ group $(\mathrm{P}<0.05)$. There were no significant difference in the expression of $11 \beta-H S D 1$ in SANFH + antler $(500 \mathrm{mg} / \mathrm{kg})$ and $\mathrm{SANFH}+$ antler $(1,000 \mathrm{mg} / \mathrm{kg})$ groups (Fig. 2 ; Table II).

In the rabbit tissue, $11 \beta$-HSD2 in both experimental groups was significantly lower than in the control group $(0.29 \pm 0.03$;

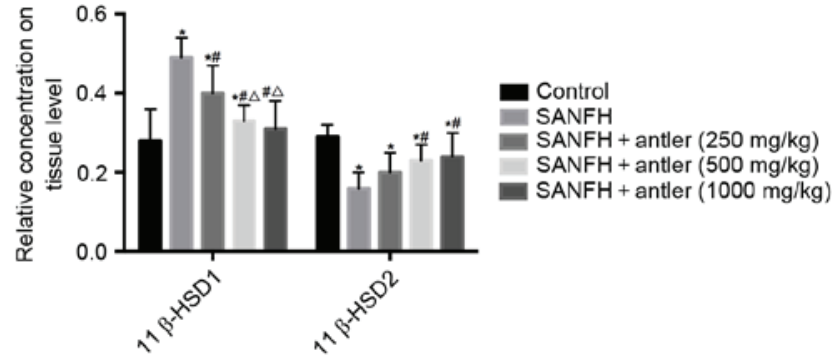

Figure 2. Relative expression of $11 \beta-H S D 1$ and $11 \beta-H S D 2$ in the rabbits' femoral head following different treatment with different concentrations of antler. ${ }^{*} \mathrm{P}<0.05$ vs. control group; ${ }^{\#} \mathrm{P}<0.05$ vs. SANFH group; ${ }^{\Delta} \mathrm{P}<0.05$ vs. SANFH + antler $(250 \mathrm{mg} / \mathrm{kg}$ ) group. $11 \beta$-HSD, $11 \beta$-hydroxysteroid dehydrogenases; SANFH, steroid-induced avascular necrosis of the femoral head.

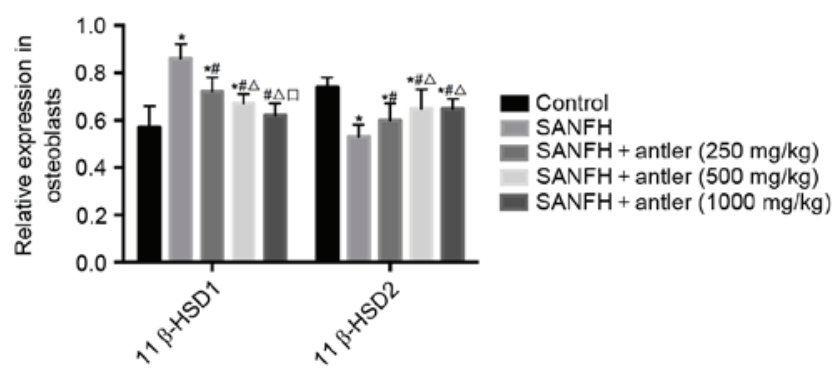

Figure 3. Relative expression of $11 \beta-H S D 1$ and $11 \beta-H S D 2$ in rabbit osteoblasts following treatment with different concentrations of antler extract. ${ }^{*} \mathrm{P}<0.05$ vs. control group; ${ }^{\#} \mathrm{P}<0.05$ vs. SANFH group; ${ }^{\wedge} \mathrm{P}<0.05$ vs. $\mathrm{SANFH}+$ antler $(250 \mathrm{mg} / \mathrm{kg})$ group; ${ }^{\square} \mathrm{P}<0.05 \mathrm{vs} . \mathrm{SANFH}+\operatorname{antler}(500 \mathrm{mg} / \mathrm{kg})$ group. 11 $\beta$-HSD; 11 $\beta$-hydroxysteroid dehydrogenase; SANFH, steroid-induced avascular necrosis of the femoral head.

$\mathrm{P}<0.05)$. Levels of $11 \beta-\mathrm{HSD} 2$ in the SANFH + antler $(500 \mathrm{mg} / \mathrm{kg})$ and SANFH + antler $(1,000 \mathrm{mg} / \mathrm{kg})$ groups $(0.23 \pm 0.04 ; 0.24 \pm 0.06$, respectively) were significantly higher than in the SANFH group $(0.16 \pm 0.04 ; \mathrm{P}<0.05)$. There were no significant differences in $11 \beta$-HSD2 between the SANFH and SANFH + antler $(250 \mathrm{mg} / \mathrm{kg})$ groups, as well as between in SANFH + antler $(500 \mathrm{mg} / \mathrm{kg})$ and in SANFH + antler $(1,000 \mathrm{mg} / \mathrm{kg})$ groups (Fig. 2 and Table II).

In osteoblasts, $11 \beta$-HSD1 levels in the SANFH, SANFH + antler $(250 \mathrm{mg} / \mathrm{kg})$ and SANFH + antler $(500 \mathrm{mg} / \mathrm{kg})$ groups $(0.86 \pm 0.06,0.72 \pm 0.06$ and $0.67 \pm 0.04$, respectively) were all significantly higher than those of the control $(0.57 \pm 0.09 ; \mathrm{P}<0.05)$. However, $11 \beta$-HSD1 levels in the SANFH + antler $(250 \mathrm{mg} / \mathrm{kg}), \mathrm{SANFH}+\operatorname{antler}(500 \mathrm{mg} / \mathrm{kg})$ and SANFH + antler $(1,000 \mathrm{mg} / \mathrm{kg})$ groups were all significantly lower than that of the SANFH group $(\mathrm{P}<0.05)$. Furthermore, $11 \beta$-HSD1 levels in the SANFH + antler $(1,000 \mathrm{mg} / \mathrm{kg})$ group were significantly lower than those of the SANFH + antler (500 mg/kg) group ( $\mathrm{P}<0.05$; Fig. 3).

In osteoblasts, levels of $11 \beta$-HSD2 in all experimental groups were significantly lower than that of the control $(0.74 \pm 0.04 ; \mathrm{P}<0.05) .11 \beta$-HSD2 levels in the SANFH + antler $(250 \mathrm{mg} / \mathrm{kg}), \mathrm{SANFH}+\operatorname{antler}(500 \mathrm{mg} / \mathrm{kg})$ and SANFH + antler $(1,000 \mathrm{mg} / \mathrm{kg})$ groups $(0.60 \pm 0.07,0.65 \pm 0.08$ and $0.65 \pm 0.04$, respectively) were all significantly higher than that of the SANFH $(0.53 \pm 0.05)$ group $(\mathrm{P}<0.05)$. 11 $\beta$-HSD2 levels in the SANFH + antler $(500 \mathrm{mg} / \mathrm{kg})$ and SANFH + antler $(1,000 \mathrm{mg} / \mathrm{kg})$ groups were significantly higher than of the 
Table II. Relative expression of $11 \beta-\mathrm{HSD} 1$ and $11 \beta-\mathrm{HSD} 2$ in the rabbit femoral heads and osteoblasts.

\begin{tabular}{|c|c|c|c|c|}
\hline \multirow[b]{2}{*}{ Groups } & \multicolumn{2}{|c|}{ Tissues } & \multicolumn{2}{|c|}{ Osteoblasts } \\
\hline & $11 \beta-H S D 1$ & $11 \beta-H S D 2$ & $11 \beta-H S D 1$ & $11 \beta-H S D 2$ \\
\hline Control & $0.28 \pm 0.08$ & $0.29 \pm 0.03$ & $0.57 \pm 0.09$ & $0.74 \pm 0.04$ \\
\hline SANFH & $0.49 \pm 0.05^{\mathrm{a}}$ & $0.16 \pm 0.04^{\mathrm{a}}$ & $0.86 \pm 0.06^{\mathrm{a}}$ & $0.53 \pm 0.05^{\mathrm{a}}$ \\
\hline SANFH + antler $(250 \mathrm{mg} / \mathrm{kg})$ & $0.40 \pm 0.07^{\mathrm{a}, \mathrm{b}}$ & $0.20 \pm 0.05^{\mathrm{a}}$ & $0.72 \pm 0.06^{\mathrm{a}, \mathrm{b}}$ & $0.60 \pm 0.07^{\mathrm{a}, \mathrm{b}}$ \\
\hline SANFH + antler $(500 \mathrm{mg} / \mathrm{kg})$ & $0.33 \pm 0.04^{\mathrm{a}-\mathrm{c}}$ & $0.23 \pm 0.04^{\mathrm{a}, \mathrm{b}}$ & $0.67 \pm 0.04^{\mathrm{a}-\mathrm{c}}$ & $0.65 \pm 0.08^{\mathrm{a}-\mathrm{c}}$ \\
\hline SANFH + antler $(1000$ mg/kg) & $0.31 \pm 0.07^{\mathrm{b}, \mathrm{c}}$ & $0.24 \pm 0.06^{\mathrm{a}, \mathrm{b}}$ & $0.62 \pm 0.05^{\mathrm{b}-\mathrm{d}}$ & $0.65 \pm 0.04^{\mathrm{a}-\mathrm{c}}$ \\
\hline
\end{tabular}

Data are presented as the mean \pm standard deviation. ${ }^{a} \mathrm{P}<0.05$ vs. control group; ${ }^{b} \mathrm{P}<0.05$ vs. SANFH group; ${ }^{c} \mathrm{P}<0.05$ vs. $\mathrm{SANFH}+$ antler $(250 \mathrm{mg} / \mathrm{kg})$ group; ${ }^{\mathrm{d}} \mathrm{P}<0.05 \mathrm{vs}$. SANFH + antler $(500 \mathrm{mg} / \mathrm{kg}) ;$ SANFH, steroid-associated femoral head necrosis. $11 \beta$-HSD; $11 \beta$-hydroxysteroid dehydrogenases.

Table III. Effect of antler-containing serum on ALP levels, proliferation and the cell cycle in osteoblasts.

\begin{tabular}{|c|c|c|c|c|c|}
\hline \multirow[b]{2}{*}{ Groups } & \multirow[b]{2}{*}{ Proliferation $(\%)$} & \multirow[b]{2}{*}{$\operatorname{ALP}(\mathrm{U} / \mathrm{l})$} & \multicolumn{3}{|c|}{ Cell cycle $(\%)$} \\
\hline & & & G0/G1 & $\mathrm{S}$ & $\mathrm{G} 2 / \mathrm{M}$ \\
\hline Control & $0.53 \pm 0.07$ & $0.64 \pm 0.12$ & $63.39 \pm 4.51$ & $28.04 \pm 4.50$ & $8.57 \pm 0.95$ \\
\hline SANFH & $0.28 \pm 0.12^{\mathrm{a}}$ & $0.25 \pm 0.16^{\mathrm{a}}$ & $75.60 \pm 3.88^{\mathrm{a}}$ & $22.05 \pm 3.63$ & $2.35 \pm 1.14$ \\
\hline SANFH + antler $(250 \mathrm{mg} / \mathrm{kg})$ & $0.33 \pm 0.07^{\mathrm{a}, \mathrm{b}}$ & $0.43 \pm 0.09^{\mathrm{a}, \mathrm{b}}$ & $70.25 \pm 4.06^{\mathrm{a}, \mathrm{b}}$ & $25.37 \pm 3.84$ & $4.38 \pm 0.87$ \\
\hline SANFH + antler (500 mg/kg) & $0.37 \pm 0.12^{\mathrm{a}, \mathrm{b}}$ & $0.56 \pm 0.11^{\mathrm{a}-\mathrm{c}}$ & $68.77 \pm 2.96^{\mathrm{a}, \mathrm{b}}$ & $26.29 \pm 2.17$ & $4.94 \pm 0.93$ \\
\hline SANFH + antler $(1,000 \mathrm{mg} / \mathrm{kg})$ & $0.40 \pm 0.17^{\mathrm{a}-\mathrm{c}}$ & $0.58 \pm 0.13^{\mathrm{a}-\mathrm{c}}$ & $67.12 \pm 3.58^{b}$ & $26.96 \pm 4.11$ & $5.92 \pm 1.06$ \\
\hline
\end{tabular}

Data are presented as the mean \pm standard deviation. ${ }^{a} \mathrm{P}<0.05$ vs. control group, $\mathrm{P}<0.05 ;{ }^{b} \mathrm{P}<0.05$ vs. SANFH group; ${ }^{\mathrm{C}}<0.05 \mathrm{vs}$. SANFH + antler $(250 \mathrm{mg} / \mathrm{kg})$ group; ALP, alkaline phosphatase; SANFH, steroid-associated femoral head necrosis.

SANFH + antler $(250 \mathrm{mg} / \mathrm{kg})$ group $(\mathrm{P}<0.05)$. However, $11 \beta$-HSD2 levels did not differ significantly between the SANFH + antler $(500 \mathrm{mg} / \mathrm{kg})$ and SANFH + antler $(1,000 \mathrm{mg} / \mathrm{kg})$ groups (Fig. 3; Table II).

ALP levels and osteoblast proliferation. The ALP concentration (U/l) and osteoblast proliferation rate $(\%)$ are presented in Table III and Fig. 4. The proliferation rates of the osteoblasts in all experimental groups were significantly lower than that of the control group $(0.53 \pm 0.07 ; \mathrm{P}<0.05)$. The proliferation rate of the SANFH + antler $(250 \mathrm{mg} / \mathrm{kg}), \mathrm{SANFH}+$ antler $(500 \mathrm{mg} / \mathrm{kg})$ and SANFH + antler $(1,000 \mathrm{mg} / \mathrm{kg})$ groups $(0.33 \pm 0.07,0.37 \pm 0.12$ and $0.40 \pm 0.17$, respectively) were all significantly higher than that of the SANFH $(0.28 \pm 0.12)$ group $(\mathrm{P}<0.05)$. The proliferation rate of the $\mathrm{SANFH}+$ antler $(1,000 \mathrm{mg} / \mathrm{kg})$ group was significantly higher than that of the $\mathrm{SANFH}+$ antler $(250 \mathrm{mg} / \mathrm{kg})$ group $(\mathrm{P}<0.05)$ but did not differ significantly from that of the SANFH + antler $(500 \mathrm{mg} / \mathrm{kg})$ group (Fig. 4; Table III).

ALP levels in all experimental groups were significantly lower than in the control $(0.64 \pm 0.12$; $\mathrm{P}<0.05)$. ALP in the SANFH + antler $(250 \mathrm{mg} / \mathrm{kg}), \mathrm{SANFH}+$ antler $(500 \mathrm{mg} / \mathrm{kg})$ and SANFH + antler $(1,000 \mathrm{mg} / \mathrm{kg})$ groups $(0.43 \pm 0.09,0.56 \pm 0.11$ and $0.58 \pm 0.13$, respectively) were all significantly higher than in the SANFH group $(0.25 \pm 0.16$; $\mathrm{P}<0.05)$. ALP in the SANFH + antler $(500 \mathrm{mg} / \mathrm{kg})$ and
SANFH + antler $(1,000 \mathrm{mg} / \mathrm{kg})$ groups were significantly higher than that of the SANFH + antler $(250 \mathrm{mg} / \mathrm{kg})$ group $(\mathrm{P}<0.05)$, however there were no significant differences in the ALP between the SANFH + antler $(500 \mathrm{mg} / \mathrm{kg})$ and $\mathrm{SANFH}+$ antler $(1,000 \mathrm{mg} / \mathrm{kg})$ groups.

Osteoblast cell cycle. As presented in Table III and Fig. 5, the proportion of osteoblasts in G0/G1 in the SANFH, SANFH + antler $(250 \mathrm{mg} / \mathrm{kg})$ and SANFH + antler $(500 \mathrm{mg} / \mathrm{kg})$ groups $(75.60 \pm 3.88,70.25 \pm 4.06$ and $68.77 \pm 2.96$, respectively) were significantly higher than that of the control $(63.39 \pm 4.51 ; \mathrm{P}<0.05)$, whereas the proportion of osteoblasts in G0/G1 in the SANFH + antler $(1,000 \mathrm{mg} / \mathrm{kg})$ group $(67.12 \pm 3.58)$ did not differ significantly from that of the control. Furthermore, the proportion of osteoblasts in G0/G1 in the SANFH + antler $(250 \mathrm{mg} / \mathrm{kg}), \mathrm{SANFH}+$ antler $(500 \mathrm{mg} / \mathrm{kg})$ and SANFH + antler $(1,000 \mathrm{mg} / \mathrm{kg})$ groups were significantly lower than that of the SANFH group $(\mathrm{P}<0.05$; Fig. 5).

\section{Discussion}

Steroids are clinically used to inhibit inflammation, allergic and immune responses in a number of diseases (42-44). For example, steroids were widely used to treat SARS during the 2003 outbreak $(45,46)$. However, the chronic use of steroids 

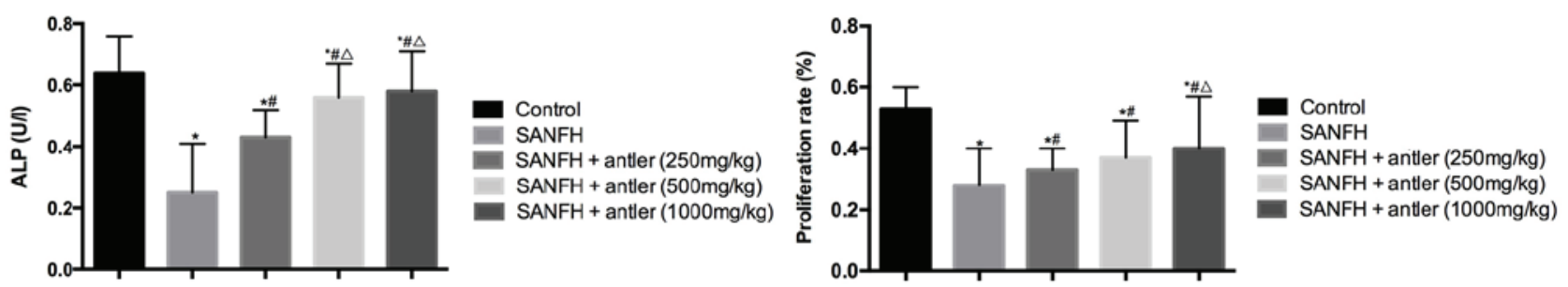

Figure 4. Effect of antler-containing serum on ALP (U/l) and proliferation (\%) in osteoblasts. ${ }^{*} \mathrm{P}<0.05$ vs. control group; ${ }^{*} \mathrm{P}<0.05$ vs. SANFH group; ${ }^{\Delta} \mathrm{P}<0.05$ vs. SANFH + antler $(250 \mathrm{mg} / \mathrm{kg})$ group. ALP, alkaline phosphatase; SANFH, steroid-induced avascular necrosis of the femoral head.

may induce severe side effects, including the onset of ANFH. Previous studies have demonstrated that the number of cases of ANFH that occur following the use of steroids is increasing (47-49). Without therapy or intervention, femoral head necrosis may become an irreversible process $(50,51)$. Previously, the majority of treatments for hip arthroplasty (52), prosthesis and reconstructive surgery (53) were surgical. However, few cases could not undergo surgical treatment.

The current study used the steroid methylprednisolone to induce and establish a model of SANFH in rabbits. Following successful establishment of the model, different concentrations of antler extract were used to treat rabbits to determine the therapeutic effect of antler extract on SANFH. Subsequently, serum CT and triglyceride levels in the rabbits were measured and it was observed that $\mathrm{CT}$ and triglyceride levels increased following the establishment of SANFH. However, CT and triglyceride levels decreased in the serum following treatment with antler extract. Serum CT levels of the rabbits in the SANFH, SANFH + antler $(250 \mathrm{mg} / \mathrm{kg})$, SANFH + antler $(500 \mathrm{mg} / \mathrm{kg})$ and SANFH + antler $(1,000 \mathrm{mg} / \mathrm{kg})$ groups were all higher than that of the control, indicating the successful establishment of the SANFH model and the presence of metabolic disorder. Serum CT levels in the SANFH + antler $(250 \mathrm{mg} / \mathrm{kg})$, SANFH + antler $(500 \mathrm{mg} / \mathrm{kg})$ and SANFH + antler $(1,000 \mathrm{mg} / \mathrm{kg})$ groups were lower than those of the SANFH group. Furthermore, serum CT levels in the SANFH + antler $(500 \mathrm{mg} / \mathrm{kg})$ and SANFH + antler $(1,000 \mathrm{mg} / \mathrm{kg})$ groups were significantly lower than in the SANFH + antler $(250 \mathrm{mg} / \mathrm{kg})$ group $(\mathrm{P}<0.05)$. Similar results were observed regarding triglyceride levels. This may be explained by the fact that SANFH induces fat embolism in the peripheral vessels, leading to intravascular coagulation (54-56). The results of the current study therefore indicate that antler extract induces a therapeutic effect on metabolic disorders in SANFH.

$11 \beta-H S D 1$ are the critical enzymes that regulate glucocorticoids in bone tissue, which are expressed in osteoblasts and osteoclasts (57) and are able to participate in oxidation and reduction reactions (58). However, the mechanisms by which steroids induce ANFH remain unclear. The current study detected and compared $11 \beta-H S D 1$ and $11 \beta-H S D 2$ expression in femoral head tissue and osteoblasts with or without treatment with different concentrations of antler extract or antler-containing serum. The results demonstrated that in the femoral head tissues of SANFH model rabbits and osteoblasts treated with differentconcentrations of antlerextract, $11 \beta-\mathrm{HSD} 1$ levels significantly decreased, whereas levels of $11 \beta-H S D 2$ significantly increased $(\mathrm{P}<0.05)$. In the femoral head tissue,

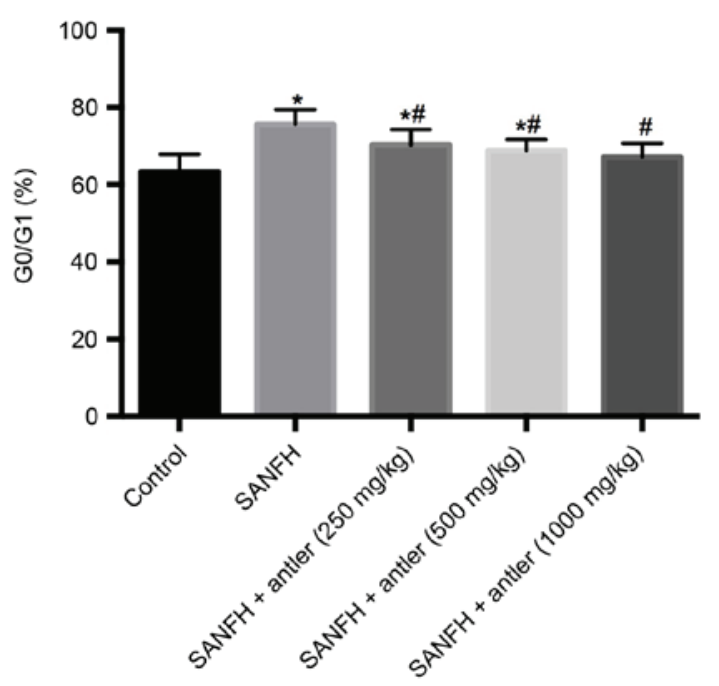

Figure 5. Effect of antler-containing serum on cell cycle in osteoblasts. " $\mathrm{P}<0.05$ vs. control group; ${ }^{\#} \mathrm{P}<0.05$ vs. SANFH group. SANFH, steroid-induced avascular necrosis of the femoral head.

$11 \beta$-HSD1 levels in the experimental groups, apart from in the SANFH + antler $(1,000 \mathrm{mg} / \mathrm{kg})$ group, were significantly higher than in the control $(\mathrm{P}<0.05)$. Levels of $11 \beta-H S D 1$ in the SANFH + antler $(250 \mathrm{mg} / \mathrm{kg})$, SANFH + antler $(500 \mathrm{mg} / \mathrm{kg})$ and SANFH + antler $(1,000 \mathrm{mg} / \mathrm{kg})$ groups were all significantly lower than that in SANFH group $(\mathrm{P}<0.05)$. 11ß-HSD2 levels in the experimental groups were lower compared with the control, significantly $(\mathrm{P}<0.05)$. Levels of $11 / \mathrm{kHSD} 2$ in the SANFH + antler $(250 \mathrm{mg} / \mathrm{kg})$, SANFH + antler $(500 \mathrm{mg} / \mathrm{kg})$ and SANFH + antler $(1,000 \mathrm{mg} / \mathrm{kg})$ groups were significantly higher than in the SANFH groups $(\mathrm{P}<0.05)$. Similar results were found regarding in osteoblasts treated with different concentrations of antler extract, with decreasing 11 $\beta-H S D 1$ and increasing $11 \beta-H S D 2$ levels. This phenomenon indicates that $11 \beta-\mathrm{HSD} 1$ is upregulated, whereas $11 \beta-\mathrm{HSD} 2$ is downregulated in SANFH. Antler induced therapeutic effects in SANFH by downregulating $11 \beta-H S D 1$ and upregulating $11 \beta$-HSD2. Following treatment with higher concentrations of antler extract, this therapeutic effect became more marked.

In order to evaluate the therapeutic effect of antler extract on SANFH, serum extracted from rabbits with SANFH that had or had not received treatment with different concentrations of antler, were used to treat osteoblasts extracted from rabbits. As well as the detection of 11 $\beta$-HSD expression, levels of ALP, which is an indicator of early osteoblastic differentiation (59), were measured and cell proliferation and the proportion of cells in each phase of the cell cycle were determined. The 
proliferation rates of the osteoblasts in all experimental groups were all significantly lower than that of the control $(\mathrm{P}<0.05)$, indicating that SANFH inhibits the proliferation of osteoblasts. The proliferation rate in the SANFH + antler $(250 \mathrm{mg} / \mathrm{kg})$, SANFH + antler $(500 \mathrm{mg} / \mathrm{kg})$ and SANFH $+\operatorname{antler}(1,000 \mathrm{mg} / \mathrm{kg})$ groups were significantly higher than that of the SANFH group $(\mathrm{P}<0.05)$ and increased as the concentration of antler extract increased, indicating that antler treatment may promote the proliferation of osteoblasts. ALP levels in all experimental groups were significantly lower than that of the control $(\mathrm{P}<0.05)$, indicating that SANFH decreases ALP levels. However, ALP levels in the SANFH + antler $(250 \mathrm{mg} / \mathrm{kg}), \mathrm{SANFH}+$ antler $(500 \mathrm{mg} / \mathrm{kg})$ and SANFH + antler $(1,000 \mathrm{mg} / \mathrm{kg})$ groups were all significantly higher than that of the SANFH group $(\mathrm{P}<0.05)$ and increased as the concentration of antler extract increased, indicating that treatment with antler extract may increase ALP levels following SANFH. The proportion of osteoblasts in the $\mathrm{G} 0 / \mathrm{G} 1$ phase $(\%)$ in the experimental groups were higher than that in the control and the proportion of osteoblasts in the SANFH + antler $(250 \mathrm{mg} / \mathrm{kg})$, SANFH + antler $(500 \mathrm{mg} / \mathrm{kg})$ and SANFH + antler $(1,000 \mathrm{mg} / \mathrm{kg})$ groups were all significantly lower than that of the SANFH group $(\mathrm{P}<0.05)$. This phenomenon demonstrates that SANFH may inhibit the proliferation of osteoblasts proliferation and attenuate the cell cycle at the G0/G1 phase. Antler extract, as a therapeutic drug, may promote the proliferation of osteoblasts and induce cellular differentiation.

In conclusion, the current study demonstrated that antler has a therapeutic effect on ANFH induced by steroids, which may promote biochemical metabolism, as well as promoting the proliferation and differentiation of osteoblasts. 11 $\beta$-HSDs may serve important roles in the development of SANFH and may be targeted by antler extract in order to prevent and treat SANFH.

\section{References}

1. Rodriguez-Merchan EC, Martinez-Lloreda A, Sanjurjo MJ and V Jimenez-Yuste: Osteonecrosis of the femoral head. In: Musculoskeletal Aspects of Haemophilia. Rodriguez-Merchan EC, Goddard NJ, Lee CA (eds). Springer Berlin, Heidelberg, pp 153-158, 2014.

2. Liakakos T, Thomakos N, Fine PM, Dervenis C and Young RL: Peritoneal adhesions: Etiology, pathophysiology and clinical significance. recent advances in prevention and management. Dig Surg 18: 260-273, 2001.

3. Fisher DE and Bickel WH: Corticosteroid-induced avascular necrosis. a clinical study of seventy-seven patients. J Bone Joint Surg Am 53: 859-873, 1971.

4. Bozic KJ, Zurakowski D and Thornhill TS: Survivorship analysis of hips treated with core decompression for nontraumatic osteonecrosis of the femoral head. J Bone Joint Surg Am 81: 200-209, 1999

5. Zaidi M, Sun L, Robinson LJ, Tourkova IL, Liu L, Wang Y, Zhu LL, Liu X, Li J, Peng Y, et al: ACTH protects against glucocorticoid-induced osteonecrosis of bone. Proc Natl Acad Sci USA 107: 8782-8787, 2010.

6. Su P, Li R, Liu S, Zhou Y, Wang X, Patil N, Mow CS, Mason JC, Huang D and Wang Y: Age at onset-dependent presentations of premature hip osteoarthritis, avascular necrosis of the femoral head, or legg-calvé-perthes disease in a single family, consequent upon a p.Gly1170Ser mutation of COL2A1. Arthritis Rheum 58: 1701-1706, 2008.

7. Liu J, Chen $\mathrm{H}$, Zhang $\mathrm{H}$, et al: Clinical characteristics and risk factors of avascular necrosis of the femoral head in patients with lupus nephritis. Chin J Nephrol Dial Transplant, 2013.

8. Zeng C, Song YC, Cai DZ and Liu B: Clinical characteristics and complication prevention of total hip arthroplasty for the patients of femoral head necrosis with systemic lupus erythematosus. Chin J Joint Surg: 454-458, 2009 (In Chinese).
9. Kawate K, Yajima H, Ohgushi H, Kotobuki N, Sugimoto K, Ohmura T, Kobata Y, Shigematsu K, Kawamura K, Tamai K and Takakura Y: Tissue-engineered approach for the treatment of steroid-induced osteonecrosis of the femoral head: Transplantation of autologous mesenchymal stem cells cultured with beta-tricalcium phosphate ceramics and free vascularized fibula. Artif Organs 30: 960-962, 2006.

10. Zhao FC, Li ZR and Guo KJ: Clinical analysis of osteonecrosis of the femoral head induced by steroids. Orthop Surg 4: 28-34, 2012.

11. LaPorte DM, Mont MA, Mohan V, Jones LC and Hungerford DS: Multifocal osteonecrosis. J Rheumatol 25: 1968-1974, 1998.

12. Barnes PJ and Adcock IM: How do corticosteroids work in asthma? Ann Intern Med 139: 359-370, 2003

13. Liu X, Zhang Y and Huo L: A study on application of protocol nursing in corticosteroids treatment compliance of nephritic syndrome patients. Chin Nurs Res 45: 539-545, 2008.

14. Lee AC and Wong LG: Facial palsy, corticosteroids, and acute leukemia. Pediatr Neurol 36: 137-138, 2007.

15. Steelman J and Kappy M: Adrenal suppression and growth retardation from ocular corticosteroids. J Pediatr Ophthalmol Strabismus 38: 177-178, 2001.

16. Morton NM: Obesity and corticosteroids: 11beta-hydroxysteroid type 1 as a cause and therapeutic target in metabolic disease. Mol Cell Endocrinol 316: 154-164, 2010.

17. Need AG: Corticosteroids and osteoporosis. Aust N Z J Med 17: 267-272, 1987.

18. Hengge UR, Ruzicka T, Schwartz RA and Cork MJ: Adverse effects of topical glucocorticosteroids. J Am Acad Dermatol 54: $1-18,2006$

19. Gebhard KL and Maibach HI: Relationship between systemic corticosteroids and osteonecrosis. Am J Clin Dermatol 2: 377-388, 2001.

20. Skalka HW and Prchal JT: Effect of corticosteroids on cataract formation. Arch Ophthalmol 98: 1773-1777, 1980.

21. Lavin PJ and Workman R: Cushing syndrome induced by serial occipital nerve blocks containing corticosteroids. Headache 41: 902-904, 2001.

22. Cranney A, Welch V, Adachi J, Homik J, Shea B, Suarez-Almazor ME, Tugwell P and Wells GA: Calcitonin for preventing and treating corticosteroid-induced osteoporosis (Review). Cochrane Database Syst Rev: CD001983, 2000.

23. Kerachian MA, Cournoyer D, Harvey EJ, Chow TY, Bégin LR, Nahal A and Séguin C: New insights into the pathogenesis of glucocorticoid-induced avascular necrosis: Microarray analysis of gene expression in a rat model. Arthritis Res Ther 12: R124, 2010.

24. Baktursun P, Peng H and Li BB: Effects of antler powder on treatment of corticosteroid-induced avascular necrosis of the femoral head in rats. J Clin Rehabilitative Tiss Eng Res 346: 1030-1031, 2011.

25. Tian L, Tian XY, Fan NN, Liang XP and YU XM: Treatment of avascular necrosis of the femoral head (ANFH) with induced differentiation VEGF-165 gene modified mesenchymal stem cells in rabbits. Journal of Shenyang Medical College: 140-144, 2009.

26. Sen RK: Management of avascular necrosis of femoral head at pre-collapse stage. Indian J Orthop 43: 6-16, 2009.

27. Pritchett JW: Statin therapy decreases the risk of osteonecrosis in patients receiving steroids. Clin Orthop Relat Res: 173-178, 2001.

28. Lai KA, Shen WJ, Yang CY, Shao CJ, Hsu JT and Lin RM: The use of alendronate to prevent early collapse of the femoral head in patients with nontraumatic osteonecrosis. J Bone Joint Surg Am 87: 2155-2159, 2005.

29. Kruuk EB, Slate J, Pemberton JM, Brotherstone S, Guinness F and Clutton-Brock T: Antler size in red deer: Heritability and selection but no evolution. Evolution 56: 1683-1695, 2002

30. Gould SJ: The origin and function of 'BIZARRE' structures: Antler size and skull size in the 'IRISH ELK,' megaloceros giganteus. Evolution 28: 191-220, 1974.

31. Chapman DI: Antler structure and function-a hypothesis. J Biomech 14: 195-197, 1981

32. Li Y, Zhao Y, Tang R and Qu X: Preventive and therapeutic effects of antler collagen on osteoporosis in ovariectomized rats. Afr J Biotechnol 9: 6437-6441, 2010.

33. Baktursun P, Peng H and Li BB. Effects of antler powder on treatment of corticosteroid-induced avascular necrosis of the femoral head in rats[J]. Journal of Clinical Rehabilitative Tissue Engineering Research 346 :1030-1031, 2011.

34. Seckl JR and Walker BR: Minireview: 11beta-hydroxysteroid dehydrogenase type 1-a tissue-specific amplifier of glucocorticoid action. Endocrinology 142: 1371-1376, 2001. 
35. Nakano D and Nishiyama A: Programmed 11ß-hydroxysteroid dehydrogenase type 2 reduction: A possible cause of adult-onset disease? J hypertens 29: 201-203, 2011.

36. Kaur K, Hardy R, Ahasan MM, Eijken M, van Leeuwen JP Filer A, Thomas AM, Raza K, Buckley CD, Stewart PM, et al: Synergistic induction of local glucocorticoid generation by inflammatory cytokines and glucocorticoids: Implications for inflammation associated bone loss. Ann Rheum Dis 69: $1185-1190,2010$

37. Kerachian MA, Séguin C and Harvey EJ: Glucocorticoids in osteonecrosis of the femoral head: A new understanding of the mechanisms of action. J Steroid Biochem Mol Biol 114: 121-128, 2009.

38. Combes $\mathrm{R}$ and Balls $\mathrm{M}$ : Comments on the sub-group reports of the EU technical expert working group on the revision of directive $86 / 609 / \mathrm{EEC}$ on the protection of animals used for experimental and other scientific purposes. Altern Lab Anim 35: $155-175,2007$

39. Wen Q, Ma L, Chen YP, Yang L, Luo W and Wang XN: A rabbit model of hormone-induced early avascular necrosis of the femoral head. Biomed Environ Sci 21: 398-403, 2008.

40. Mont MA, Jones LC, Einhorn TA, Hungerford DS and Reddi AH: Osteonecrosis of the femoral head. Potential treatment with growth and differentiation factors. Clin Orthop Relat Res (355 Suppl): S314-S335, 1998.

41. Baneux PJ, Garner D, Mcintyre HB and Holshuh HJ: Euthanasia of rabbits by intravenous administration of ketamine. J Am Vet Med Assoc 189: 1038-1039, 1986.

42. Glenn EM: Steroids, nonsteroids, intermediary metabolism, inflammation and their probable interrelationships. Hormonal Steroids Biochem Pharmacol Ther 1: 319-349, 1964.

43. Hemphill N and Morgan DR: Speaker: For inflammation, steroids should be used boldly. Primary Care Optometry News, April 2013. https://www.healio.com/footer/healio-dot-com/ about-the-wyanoke-group

44. Denso P: Free communications-session 1-inflammation \& steroidsfree. Clin Experiment Aller 23: 75-76, 1993.

45. Griffith JF, Antonio GE, Kumta SM, Hui DS, Wong JK, Joynt GM, Wu AK, Cheung AY, Chiu KH, Chan KM, et al: Osteonecrosis of hip and knee in patients with severe acute respiratory syndrome treated with steroids. Radiology 235: 168-175, 2005.

46. Chen RC, Tang XP, Tan SY, Liang BL, Wan ZY, Fang JQ and Zhong N: Treatment of severe acute respiratory syndrome with glucosteroids: The guangzhou experience. Chest 129: 1441-1452, 2006.
47. Rapała K, Walczak P and Truszczyńska A: Orthopedic diagnostic and therapeutic problems in avascular poststeroid necrosis of femur head in the course acute lymphoblastic leukemia-description of 3 cases. Chir Narzadow Ruchu Ortop Pol 75: 121-125, 2010.

48. Wu D, Song D, Ni J and Dai R: Avascular necrosis of the femoral head due to the bilateral injection of heroin into the femoral vein: A case report. Exp Ther Med 6: 1041-1043, 2013.

49. Iwata H, Hasegawa Y, Mizuno M, Genda E, Kataoka Y and Kada A: Progression of avascular necrosis of femoral head and choice of treatment. Nagoya J Med Sc 54: 27-39, 1992.

50. Jones LC and Hungerford DS: Osteonecrosis: Etiology, diagnosis, and treatment. Curr Opin Rheumatol 16: 443-449, 2004.

51. Hungerford DS: Treatment of osteonecrosis of the femoral head: Everything's new. J Arthroplasty 22 (4 Suppl 1): S91-S94, 2007.

52. Fritsch EW and Gleitz M: Ceramic femoral head fractures in total hip arthroplasty. Clin Orthop Relat Res: 129-136, 1996.

53. Cabanela ME: The bipolar prosthesis in avascular necrosis of the femoral head. Semin Arthroplasty 2: 228-233, 1991.

54. Kawai K, Tamaki A and Hirohata K: Steroid-induced accumulation of lipid in the osteocytes of the rabbit femoral head. A histochemical and electron microscopic study. J Bone Joint Surg Am 67: 755-763, 1985.

55. Jones JP Jr: Fat embolism and osteonecrosis. Orthop Clin North Am 16: 595-633, 1985

56. Jones JP Jr and Sakovich L: Fat embolism of bone. A roentgenographic and histological investigation, with use of intra-arterial lipiodol, in rabbits. J Bone Joint Surg Am 48: 149-164, 1966.

57. Cooper MS, Walker EA, Bland R, Fraser WD, Hewison M and Stewart PM: Expression and functional consequences of 11beta-hydroxysteroid dehydrogenase activity in human bone. Bone 27: 375-381, 2000.

58. Cooper MS, Rabbitt EH, Goddard PE, Bartlett WA, Hewison M and Stewart PM: Osteoblastic 11beta-hydroxysteroid dehydrogenase type 1 activity increases with age and glucocorticoid exposure. J Bone Miner Res 17: 979-986, 2002.

59. Chen XP, Qian H, Wu JJ, Ma XW, Gu ZX, Sun HY, Duan YZ and Jin ZL: Expression of vascular endothelial growth factor in cultured human dental follicle cells and its biological roles. Acta Pharmacol Sin 28: 985-993, 2007. 